\title{
NOWE REGULACJE FUNKCJONOWANIA ZWIĄZKÓW ZAWODOWYCH - WYBRANE ZAGADNIENIA
}

\author{
Abstract \\ New regulations of trade unions activities - selected issues
}

The paper presents the provisions of the amended law that entered into force on 1 of January 2019 and which regulates the activities of trade unions. The main focus of the paper is on workers, which includes independent contractors, who have the right to organise a trade union. The analysis also includes the rights provided in regulations about trade unions; specifically, the right to information, right to protection against dismissal of independent contractors that are members of trade unions. The paper also refers to the right to strike and the right to be released for ad hoc activities.

Słowa kluczowe: związek zawodowy, wolność zrzeszania się, osoby zatrudnione na umowach cywilnoprawnych, prawa związków zawodowych

Keywords: trade union, freedom of association, independent contractors, trade unions' rights

ASJC: 3308, JEL: K31

Od 1 stycznia 2019 r. obowiązują nowe przepisy określające osoby, które mogą zakładać i wstępować do związków zawodowych. Prawo takie zyskają między innymi osoby wykonujące pracę na podstawie umów cywilnoprawnych (zleceniobiorcy i usługobiorcy). Zmiana ta rodzi wiele wątpliwości dotyczących funkcjonowania związków zawodowych po tej dacie.

Dotychczas prawo do tworzenia związków zawodowych przysługiwało co do zasady przede wszystkim pracownikom; prawa tego były pozbawione osoby wykonujące pracę na podstawie umowy cywilnoprawnej czy osoby samozatrudnione (Florek 2018, s. 55 i n.). Rozwiązanie to zostało jednak uznane za niezgodne z Konstytucją (Dz.U. 1997, nr 78, poz. 483 ze zm., dalej: „Konstytucja”) przez Trybunał Konstytucyjny w wyroku z 2 czerwca 2015 r., K 1/13 (Dz.U. 2005, poz. 791). Trybunał uznał w nim za niekonstytucyjne przepisy ustawy z dn. 23 maja 1991 r. o związkach zawodowych (Dz.U. 2014, poz. 167 tekst jedn. ze zm., dalej: „ustawa o związkach zawodowych”, „u.z.z.”) w zakresie, w jakim ogranicza wolność tworzenia i wstępowania do związków zawodowych osobom wykonującym pracę zarobkową niebędącym pracownikami. Również Międzynarodowa 
Organizacja Pracy w rekomendacji z 28 marca 2012 r. zwróciła uwagę, że konieczne jest podjęcie działań:

[...] w celu zapewnienia, by wszystkim osobom zatrudnionym, bez jakiegokolwiek rozróżnienia, łącznie z osobami samozatrudnionymi oraz zatrudnionymi na podstawie umów cywilnoprawnych, przyznano prawo tworzenia i przystępowania, wedle swego wyboru, do organizacji w rozumieniu konwencji $\mathrm{nr} 87^{1}$.

\section{Zakres podmiotowy wolności zrzeszania się w związkach zawodowych}

W celu realizacji powyższych wytycznych dokonano zmiany w ustawie o związkach zawodowych (ustawa $\mathrm{z}$ dn. 5 lipca 2018 r. o zmianie ustawy o związkach zawodowych oraz niektórych innych ustaw, Dz.U. 2018, poz. 1608), przyznając prawo do tworzenia związku zawodowego wszystkim osobom wykonującym pracę zarobkową (art. 2 u.z.z.). Osobami takimi są nie tylko pracownicy, ale również osoby świadczące prace na innej podstawie niż stosunek pracy, pod warunkiem jednak że:

1) za wykonywaną pracę otrzymują wynagrodzenie,

2) do wykonywania tej pracy nie zatrudniają innych osób,

3) mają takie prawa i interesy związane $z$ wykonywaniem pracy, które mogą być reprezentowane i bronione przez związek zawodowy (Baran 2018, s. 2-4).

Mimo sformułowania przesłanek określających, kto jest uprawniony zakładać związki zawodowe, nadal wiele zagadnień budzi wątpliwości.

Świadczenie pracy na innej podstawie niż stosunek pracy obejmuje przede wszystkim zatrudnienie na podstawie umowy cywilnoprawnej. Będą tu wchodziły w grę zarówno umowy o świadczenie usług, umowy zlecenia, jak i umowy o współpracę. Związek zawodowy będzie więc mógł być założony wyłącznie przez usługobiorców danego podmiotu oraz przy ich współudziale. Prawo to obejmuje osoby prowadzące jednoosobową działalność gospodarczą. Prawo tworzenia związku zawodowego przysługuje również członkom zarząadów spółek handlowych otrzymującym wynagrodzenie z tytułu sprawowanej funkcji czy osobom zajmującym stanowiska kierownicze. Może to prowadzić do powstania związków zawodowych menadżerów - rodzi się wątpliwość, czy faktycznie tego typu związki zawodowe będą działały w interesie pracowników, czy raczej będą miały przymiot żółtych związków zawodowych, bardziej dbających o interes samego pracodawcy.

Przepisy nie określają, jaka ma być intensywność współpracy między podmiotami zatrudnionymi na innych podstawach niż stosunek pracy a pracodawcą, u którego mieliby założyć związek zawodowy. Możliwe byłoby przyjęcie, w szczególności ze względu na

${ }^{1}$ Zob. http://www.ilo.org/dyn/normlex/en/f?p=1000:50002:0::NO:50002:P50002_COMPLAINT_ TEXT_ID:3057194 (dostęp: 1.07.2019). 
tekstualne brzmienie przepisu, że prawo do tworzenia związków zawodowych przysługuje tylko tym usługobiorcom, którzy faktycznie dostarczają usługi. Tym samym osoby z podpisaną stałą umową o świadczenie usług, która jednak nie generuje żadnych prac (lub jest podstawą wykonywania usług sporadycznie), takiego uprawnienia nie posiadają. Takie rozwiązanie rodziłoby jednak ryzyko dużego zróżnicowania osób zatrudnionych na innej podstawie niż stosunek pracy. W skrajnych przypadkach mogłoby to prowadzić do sytuacji, w której w pierwszej części dnia dana osoba (kiedy aktywnie świadczy usługę) byłaby uprawniona do zakładania i przynależności do związku zawodowego, a traciłaby te prawa w drugiej części (kiedy dane zlecenie cząstkowe zostałoby już wykonane i opłacone, a do momentu zlecenia kolejnych czynności usługa nie byłaby świadczona). Należy odrzucić takie stanowisko, gdyż prowadzi ono do rozwiązań, które w praktyce nie mogłyby być stosowane. Z tego względu należy przyjąć, że o prawie do zakładania związku zawodowego decyduje istnienie obowiązującej umowy (ewentualnie innego stosunku prawnego) będącej podstawą świadczenia pracy.

Rodzi się również pytanie, czy w świetle nowych przepisów związek zawodowy u pracodawcy użytkownika będzie mógł być założony przez pracujących na jego rzecz pracowników tymczasowych. Na tak postawione pytanie należy, moim zdaniem, udzielić odpowiedzi negatywnej. Przemawia za tym definicja pracodawcy sformułowana w ustawie o związkach zawodowych. Na potrzeby tej ustawy przez pracodawcę należy rozumieć pracodawcę w rozumieniu art. 3 ustawy z dn. 26 czerwca 1974 r. - Kodeks pracy (Dz.U. 2019, poz. 1040 tekst jedn. ze zm., dalej: „Kodeks pracy”, „k.p.”) oraz jednostkę organizacyjną, choćby nie posiadała osobowości prawnej, a także osobę fizyczną, jeżeli zatrudniają one inną niż pracownik osobę wykonującą pracę zarobkową, niezależnie od podstawy tego zatrudnienia (art. $1^{1}$ pkt 2 u.z.z.).

Z powyższego należy wnioskować, że warunkiem przyznania danej osobie prawa do zakładania związku zawodowego u danego pracodawcy jest, by była ona zatrudniana przez ten podmiot. Pracownicy tymczasowi wprawdzie świadczą pracę na rzecz pracodawcy użytkownika, ale pozostają w zatrudnieniu z agencją pracy tymczasowej, i to właśnie u niej mogą utworzyć związek zawodowy.

Można zastanawiać się, czy takie rozwiązanie jest słuszne, skoro pracownicy tymczasowi świadczą pracę w zakładzie pracy należącym do pracodawcy użytkownika, i to właśnie on ma wpływ na część warunków, w jakim praca pracowników tymczasowych jest wykonywana. Z dużą ostrożnością podchodzę do przyznania prawa zakładania organizacji związkowej przez pracowników tymczasowych u pracodawcy użytkownika. Mogłoby to prowadzić do wypaczenia obecnej trójstronnej koncepcji stosunku pracy tymczasowej i jeszcze większego niż dotychczas zmarginalizowania pozycji agencji pracy tymczasowej jako pracodawcy. To agencja powinna podejmować negocjacje z pracodawcą użytkownikiem w celu zagwarantowania odpowiednich warunków pracy zatrudnianym przez siebie pracownikom tymczasowym. Rozwiązaniem kompromisowym mogłoby być przyznanie związkom zawodowym tworzonym u agencji pracy tymczasowej prawa podejmowania rokowań z pracodawcą użytkownikiem odnośnie zagadnień wpływających na sytuację prawną pracowników tymczasowych. 
Kolejnym warunkiem przyznania prawa do zakładania związku zawodowego jest, by za wykonywaną pracę dana osoba otrzymywała wynagrodzenie (Baran 2018, s. 3). Wynagrodzenie to może mieć dowolną formą. Przepisy nie określają również jego minimalnej wysokości. Nawet więc niewielkie kwoty otrzymywane za świadczone usługi nie będą przeszkodą, by dana osoba znalazła się wśród założycieli związku zawodowego. Wymóg otrzymywania wynagrodzenia będzie oznaczał, że związku zawodowego nie będą mogli założyć wolontariusze czy praktykanci świadczący pracę bez wynagrodzenia.

Osoby świadczące pracę na innej podstawie niż stosunek pracy nie będą miały możliwości zakładania i wstępowania do związku zawodowego, jeśli zatrudniają do wykonywania pracy inne osoby. Nie ma przy tym, w mojej ocenie, znaczenia, czy zatrudnienie tych osób będzie na podstawie umowy o pracę czy innego stosunku prawnego (umowy o świadczenie usług, umowy o współpracę etc.). Rozwiązanie takie ma zapobiec sytuacji, w której podmioty będące pracodawcami (a więc mające co do zasady inne interesy niż osoby zatrudnione) będą jednocześnie członkami związku zawodowego.

Warto wskazać jednak, że powstaje wątpliwość, co w sytuacji gdy dana osoba posiada jednocześnie status pracownika i niepracownika (np. dana osoba, oprócz zatrudnienia na podstawie umowy o pracę, wykonuje jednocześnie pozarolniczą działalność gospodarczą). Należy przyjąć, że w takim przypadku osoba w ramach swojego statusu pracowniczego będzie posiadała prawo koalicji, nawet jeśli w ramach prowadzonej działalności gospodarczej zatrudnia inne osoby. Podobnie należy rozstrzygać sytuacje, gdy jedna osoba posiada kilka umów zleceń, ale tylko w ramach jednej z nich zatrudnia osoby. Tylko w ramach takiej umowy nie będzie ona posiadała prawa do tworzenia związku zawodowego; prawo koalicji będzie jej przysługiwało w odniesieniu do innych stosunków prawnych, na podstawie których świadczy pracę.

Ostatnim warunkiem przyznania prawa do tworzenia związku zawodowego danej osobie jest to, by miała takie prawa i interesy związane $\mathrm{z}$ wykonywaniem pracy, które mogą być reprezentowane i bronione przez związek zawodowy. Nie do końca wiadomo, o jakie prawa i interesy chodziło ustawodawcy i które z nich nie będą mogły być reprezentowane przez związek. Wydaje się, że celem wprowadzenia tego wymogu było wyeliminowanie możliwości zakładania związku zawodowego przez te podmioty, które nie mają statusu zbliżonego do pracowników i w stosunku do których trudno mówić o ich „zatrudnianiu”. Dla przykładu można wskazać, że praw i interesów, które mogą być reprezentowane i bronione przez związki zawodowe, nie będą miały osoby fizyczne świadczące jednostkowe usługi na rzecz danego podmiotu (np. w zakresie usług księgowych) - w ich przypadku trudno będzie znaleźć kwestie, które mogłyby być przedmiotem negocjacji prowadzonych przez związki zawodowe.

Prawo tworzenia związków zawodowych uzyskały także osoby skierowane do pracodawców w celu odbycia służby zastępczej.

Nowe przepisy ustawy o związkach zawodowych rozszerzają również grupę podmiotów, które wprawdzie nie mogą tworzyć związków zawodowych, ale mogą do nich wstępować. Dotychczas byli to emeryci, renciści oraz osoby bezrobotne (Tomaszewska 2014, s. 223 i n.). Od 1 stycznia 2019 r. są to również wolontariusze, stażyści i inne osobom, które świadczą 
osobiście pracę bez wynagrodzenia (np. mogą to być praktykanci). Ta grupa będzie mogła przystąpić do związku zawodowego, o ile będzie na to pozwalał jego status.

Rozszerzenie zakresu podmiotów, które mogą tworzyć związki zawodowe i przystępować do nich, daje tym zatrudnionym możliwość wywierania presji na pracodawcę w celu poprawy ich warunków pracy. Dotychczas te osoby były pozbawione realnych środków nacisku na przedsiębiorcę, na rzecz którego świadczyli pracę, w celu poprawy warunków pracy. Uzyskują one również liczne uprawnienia (jak np. prawo do ochrony przed zwolnieniem czy zwolnienie na dokonanie czynności doraźnej). Warto wskazać, że związki zawodowe nie muszą informować pracodawcy, u którego działają, że przystąpiły do niego osoby, które pracują na podstawie innej niż stosunek pracy. Dla wielu pracodawców może więc być zaskoczeniem fakt żądania przez związki zawodowe poprawy sytuacji osób pracujących na podstawie umów cywilnoprawnych.

Wydaje się, że zaczną powstawać również związki zawodowe złożone z osób świadczących pracę wyłącznie na innej podstawie niż stosunek pracy. Może to rodzić konflikty z dotychczas istniejącymi związkami zawodowymi - interesy pracowników i osób wykonujących pracę zarobkową na innej podstawie będą często rozbieżne.

\section{Liczebność organizacji związkowej jako warunek korzystania z uprawnień}

Nowe regulacje wskazują, że uprawnienia zakładowej organizacji związkowej przysługują pod warunkiem zrzeszania co najmniej 10 członków (Dubowik 2003, s. 25; 2006, s. 17-18) będących:

1) pracownikami u pracodawcy objętego działaniem danej organizacji lub

2) innymi niż pracownicy osobami wykonującymi pracę zarobkową, które świadczą pracę przez co najmniej 6 miesięcy na rzecz pracodawcy objętego działaniem tej organizacji (art. $25^{1}$ ust. 1 u.z.z.).

W pierwszej kolejności należy wskazać, że pełnia praw będzie przysługiwała zarówno organizacji związkowej, która zrzesza wyłącznie pracowników, jak i tej, której członkami są wyłącznie osoby wykonujące pracę zarobkową na innej podstawie niż umowa o pracę (np. usługobiorcy; Czarnecki i in. 2019, s. 160-163). W grę może wchodzić również sytuacja, w której do organizacji związkowej należą obie te grupy. Osoby niebędące pracownikami wykonujące pracę zarobkową są uwzględniane przy ustaleniu liczebności związku zawodowego, wyłącznie jeśli świadczą pracę przez co najmniej 6 miesięcy na rzecz pracodawcy objętego działaniem danej organizacji związkowej. Wymóg ten nie dotyczy pracowników. Ustawodawca w uzasadnieniu ustawy nowelizującej przepisy ustawy o związkach zawodowych wskazuje, że wymóg sześciomiesięcznego stażu:

[...] ma na celu zapobiegnięcie sytuacji, w której uprawnienia zakładowej organizacji związkowej przysługiwałyby podmiotom zrzeszającym osoby, które nie pozostają w więzi z pracodawcą [...] [co jest motywowane] [...] koniecznością racjonalizacji przepisów objętych zmianami. 
W uzasadnieniu ustawy podniesiono, że dopiero:

[...] współpraca z pracodawcą przez okres co najmniej 6 miesięcy powoduje, że między tymi podmiotami tworzy się więź dostatecznie trwała, pozwalającą na uwzględnienie danej osoby w łącznej liczbie członków, od której ustawa uzależnia przyznanie uprawnień zakładowej organizacji związkowej.

W mojej ocenie odmienne traktowanie pracowników i osób świadczących pracę na innej podstawie niż stosunek pracy może być uznane za naruszające konstytucyjną zasadę równości i zasadę swobody zrzeszania się. Nie można więc wykluczyć, że w przyszłości to rozwiązanie zostanie zakwestionowane jako sprzeczne z ustawą zasadniczą.

Ustawodawca nie zdefiniował, jak należy liczyć sześciomiesięczny okres świadczenia pracy na rzecz pracodawcy. Po pierwsze należy przyjąć, że zastosowanie znajdą tu przepisy ustawy z dn. 23 kwietnia 1964 r. - Kodeks cywilny (Dz.U. 2019, poz. 1145 tekst jedn.), zgodnie z którymi 1 miesiąc to $30 \mathrm{dni}$. Po drugie należy mieć na względzie, że okres sześciomiesięczny nie musi mieć charakteru ciągłego, lecz może być poprzedzielany przerwami, w których dana osoba nie jest związana umową z przedsiębiorcą. Po trzecie należy wskazać, że literalne brzmienie przepisów sugeruje, że przy liczeniu okresu świadczenia pracy należy uwzględnić tylko faktyczny okres jej wykonywania. Takie rozwiązanie rodziłoby jednak ryzyko dużego zróżnicowania sytuacji osób zatrudnionych na innej podstawie niż stosunek pracy. W skrajnych przypadkach mogłoby to prowadzić do sytuacji, w której pierwsza część dnia (kiedy aktywnie świadczona jest usługa) byłaby wliczana do okresu świadczenia pracy, a takiego charakteru nie miałaby druga część dnia (kiedy dane zlecenie zostałoby już wykonane, a do momentu zlecenia kolejnych czynności usługa faktycznie nie byłaby świadczona). Należy odrzucić takie podejście, gdyż prowadzi ono do rozwiązań, które w praktyce nie mogłyby być stosowane. $Z$ tego względu powinno się przyjąć, że cały okres, w którym obowiązuje umowa pomiędzy spółką a usługobiorcą, trzeba uwzględnić przy ustalaniu, czy spełniony został wymóg sześciomiesięcznego okresu świadczenia pracy, niezależnie od tego, czy w ramach tej umowy w danym momencie usługi są faktycznie świadczone.

Sześciomiesięczny okres świadczenia pracy dotyczy współpracy z konkretnym podmiotem. Zmiana w tym zakresie będzie skutkowała koniecznością liczenia wyżej wymienionego okresu od początku. Wątpliwość powstaje, w przypadku gdy osoba wykonująca pracę zarobkową pracuje kolejno u pracodawców objętych działalnością tej samej organizacji międzyzakładowej. W mojej ocenie w takim przypadku okres zatrudniania u pierwszego pracodawcy powinien być zaliczany do stażu sześciomiesięcznego liczonego u kolejnego. Przemawia za tym brzmienie przepisu art. $25^{1}$ ust. 1 u.z.z., który nie precyzuje, że praca ma być wykonywana tylko na rzecz jednego pracodawcy, lecz wskazuje jedynie, by pracodawca ten był objęty działalnością organizacji związkowej (w przypadku organizacji międzyzakładowej działalnością taką będzie objęty każdy z pracodawców, w której ona funkcjonuje). Nadto wydaje się, że konieczność liczenia okresu od początku u każdego z pracodawców byłaby nadmiernym obciążeniem dla organizacji związkowej. Należy jednak zauważyć, że takie podejście może rodzić liczne 
trudności w ustaleniu, czy poszczególne osoby spełniły wymóg sześciomiesięcznego okresu świadczenia pracy.

Ustalenie, ile osób liczy związek zawodowy, będzie dokonywane na podstawie informacji przekazywanej przez sam związek zawodowy pracodawcy (Czubak 2003, s. 16; Płażek, Sobczyk 2003, s. 23; Dubowik 2006, s. 17; Szmit 2012, s. 420-422). Informacja powinna obejmować stan na dzień 30 czerwca i 31 grudnia (art. $25^{1}$ ust. 2 u.z.z.). Obowiązek informacyjny powinien być realizowany co 6 miesięcy - w terminie do 10. dnia miesiąca następującego po dniu 30 czerwca i 31 grudnia. Szczególne zasady dotyczą organizacji związkowych, które powstały w trakcie roku. Są one zobowiązane przekazać informacje o liczbie członków w terminie 2 miesięcy od dnia powstania, według stanu na dzień przekazania informacji. Powyższe nie wyłącza jednak w ich przypadku ogólnego obowiązku przekazania danych o liczebności według stanu na dzień 30 czerwca i 31 grudnia (art. $25^{1}$ ust. 3 u.z.z.). Informacja nie musi zawierać danych imiennych członków związku zawodowego; wystarczy samo przekazanie danych o stanie liczbowym danego związku zawodowego.

Brak wywiązania się z obowiązku informacyjnego pociąga za sobą dla związku istotne konsekwencje. Organizacja związkowa, która zaniecha przekazania danych o liczebności, traci uprawnienia, choćby w rzeczywistości liczyła więcej niż 10 uprawnionych członków (art. $25^{1}$ ust. 6 u.z.z.). Oznacza to, że taka organizacja związkowa nie będzie miała uprawnień do podejmowania działań w zakresie zbiorowych (np. wszczynanie sporu zbiorowego, udziału w konsultacjach aktów prawa zakładowego) i indywidualnych interesów pracowniczych (m.in. konsultowanie zamiaru rozwiązania umowy o pracę z pracodawcą, wyrażanie zgody na zakończenie stosunku pracy ze szczególnie chronionym działaczem związkowym). Pracodawca może więc z upływem 10. dnia po zakończeniu półrocza, w którym miał uzyskać informację, podejmować samodzielnie wszelkie czynności z zakresu indywidualnego i zbiorowego prawa pracy tak, jakby związek zawodowy w ogóle nie istniał. Aby odzyskać uprawnienia, konieczne jest dopełnienie obowiązku informacyjnego. Od momentu wywiązania się z nałożonych obowiązków przekazania danych organizacja związkowa znów może korzystać ze wszystkich swoich kompetencji. Jednak działania, które przed dopełnieniem obowiązku informacyjnego zostały dokonane przez pracodawcę bez współdziałania z organizacją związkową, pozostają skuteczne i prawidłowe, nawet jeśli z przekazanych informacji wynika, że w ich trakcie organizacja związkowa liczyła więcej niż 10 osób.

Warto wskazać, że dla posiadania uprawnień istotne jest, czy związek liczył co najmniej 10 osób w dniu wskazanym w informacji przekazanej pracodawcy. Zmiany stanu liczbowego, które nastąpią w ciągu sześciomiesięcznego okresu sprawozdawczego, pozostają bez wpływu na te uprawnienia (art. $25^{1}$ ust. 11 u.z.z.).

Nie można wykluczyć sytuacji, że ta sama osoba będzie należała do kilku związków zawodowych. W takim wypadku ustawodawca zastrzegł, że może ona być uwzględniona przy ustalaniu liczebności tylko jednego związku zawodowego (art. $25^{1}$ ust. 5 u.z.z.). Nie wskazał jednak, jak należy ustalić, do którego związku zawodowego należy zakwalifikować daną osobę. Najwłaściwszym rozwiązanie będzie, by sam członek zadeklarował, przy 
ustaleniu liczebności, w ramach którego związku chciałby być uwzględniony. Gdyby jednak stosownej deklaracji nie dokonał, takiej osoby nie należy uwzględniać przy ustalaniu liczebności któregokolwiek ze związków zawodowych. Tylko takie rozwiązanie pozwoli zapobiec kolizji z wymaganiami stawianymi przez obowiązujące przepisy.

\section{Weryfikacja liczebności organizacji związkowej}

Informacja przekazywana pracodawcy nie musi zawierać danych imiennych członków związku zawodowego - wystarczy samo przekazanie danych o stanie liczbowym. Rodziło to dotychczas często wątpliwości. Pracodawcy często nie byli pewni, czy dane liczbowe przekazane przez organizacje związkowe odpowiadają rzeczywistemu stanowi rzeczy. Nowe przepisy dają im możliwość wszczęcia w tym zakresie procedury weryfikacyjnej. Pracodawca może zgłosić pisemne zastrzeżenie co do liczebności danej zakładowej organizacji związkowej w terminie 30 dni od dnia przedstawienia przez tę organizację informacji o swojej liczebności (art. $25^{1}$ ust. 7 u.z.z.). Zastrzeżenie jest składane bezpośrednio organizacji związkowej, której dotyczy. Z treści zastrzeżenia pracodawcy powinno jasno wynikać, że jest ono dokonywane w ramach procedury weryfikacyjnej przewidzianej w ustawie o związkach zawodowych (np. przez powołanie się na odpowiedni przepis). Zastrzeżenia muszą mieć formę pisemną - wykluczone jest wysyłanie e-maila lub ustne sformułowanie wątpliwości. Wreszcie pisma z zastrzeżeniami powinny być podpisane przez pracodawcę lub inną osobę, która została przez pracodawcę upoważniona do reprezentowania go w stosunkach ze związkami zawodowymi.

W razie wniesienia zastrzeżeń organizacja związkowa ma 30 dni liczone od dnia sformułowania zastrzeżeń przez pracodawcę na wystąpienie do sądu $\mathrm{z}$ wnioskiem o ustalenie liczby członków. Jeśli takiego działania nie podejmie, to z upływem ostatniego dnia powyższego terminu traci wszelkie uprawnienia przyznane organizacji związkowej. Wniosek powinien zostać skierowany przez związek do sądu rejonowego - sądu pracy właściwego ze względu na siedzibę pracodawcy. W przypadku organizacji międzyzakładowych należy przyjąć, że wniosek może być złożony do sądu właściwego dla któregokolwiek z pracodawców objętych działalnością danej organizacji międzyzakładowej. We wniosku należy przedstawić dowody potwierdzające, iż dane o liczbie członków przekazane pracodawcy są prawdziwe. Najlepiej, by były to deklaracje członkowskie lub imienna lista członków z podpisami poszczególnych osób.

Sąd prowadzi postępowanie $\mathrm{z}$ wniosku organizacji związkowej w trybie nieprocesowym (art. $25^{1}$ ust. 8 u.z.z.). Zastosowanie znajdą tu przepisy art. 506-525 ustawy z dn. 17 listopada 1964 r. - Kodeks postępowania cywilnego (Dz.U. 2018, poz. 1360 tekst jedn. ze zm.). Sąd powinien zadbać, by wszystkie podmioty zainteresowane miały możliwość wzięcia udziału. W toku prowadzonego postępowania sąd ma prawo żądać od wnioskodawcy oraz ewentualnych uczestników informacji i wyjaśnień lub przedłożenia odpowiednich dowodów. Od wydanego przez sąd orzeczenia przysługuje apelacja. W postępowaniu może wziąć udział, oprócz organizacji związkowej, również pracodawca lub inna 
organizacja związkowa działająca u tego samego pracodawcy. Będą one uprawnione do przedstawiania swojego stanowiska i przedkładania dowodów dotyczących prawdziwości danych przekazanych przez organizację związkową, której liczebność jest weryfikowana. Ustawodawca, ze względu na zasadę niezależności związkowej, ograniczył jednak prawo dostępu do danych osobowych członków związku. Może się z nimi zapoznać w ramach postępowania, oprócz samej organizacji związkowej, wyłącznie sąd (art. $25^{1}$ ust. 10 u.z.z.). Ma to zapobiec sytuacji wykorzystywania przez pracodawcę procedury weryfikacyjnej do zdobycia informacji o członkach związków zawodowych, które u niego działają. Jest to również motywowane tym, że dane o członkostwie mają charakter danych osobowych wrażliwych.

Sąd ustala, ilu członków liczyła organizacja związkowa ostatniego dnia danego półrocza, a więc 30 czerwca lub 31 grudnia, w zależności od tego, którego okresu dotyczyło zastrzeżenie wniesione przez pracodawcę (art. $25^{1}$ ust. 8 u.z.z.).

Ustawodawca wyraźnie narzucił sądowi termin, w jakim powinno nastąpić zweryfikowanie wniosku organizacji związkowej. Ma na to 60 dni od dnia złożenia wniosku (art. $25^{1}$ ust. 8 u.z.z.). Termin ten ma jednak charakter wyłącznie instrukcyjny - jego uchybienie nie wpływa na ważność orzeczenia ani nie pozwala przyjąć, że sąd przychylił się do któregokolwiek stanowiska.

Należy zauważyć, że procedura weryfikacyjna może być kłopotliwa dla związku zawodowego, gdyż nie tylko angażuje ona jego zarząd, ale również może budzić obawy jego członków, czy ich dane nie zostaną ujawnione pracodawcy. Może być również wykorzystywana jako środek nacisku pracodawcy na organizację związkową. By temu zapobiec, wprowadzono ograniczenia częstotliwości, z jaką można zgłaszać zastrzeżenia co do wiarygodności danych o członkostwie. Jeżeli uprzednio zgłoszone przez pracodawcę zastrzeżenie dotyczące liczebności danej organizacji związkowej okazało się bezpodstawne, ponowne zgłoszenie przez te podmioty zastrzeżenia odnośnie do liczebności tej samej organizacji związkowej może nastąpić nie wcześniej niż po upływie roku od dnia uprawomocnienia się orzeczenia w sprawie ustalenia liczby członków tej organizacji (art. $25^{1}$ ust. 12 u.z.z.).

Prawo wnoszenia zastrzeżeń co do danych o liczebności związku zawodowego przysługuje nie tylko pracodawcy, ale również innym działającym u niego związkom zawodowym. Aby inne działające u pracodawcy organizacje związkowe miały możliwość oceny prawdziwości danych o liczebności, są one udostępniane przez pracodawcę do wglądu na pisemny wniosek tej organizacji. Prawo to przysługuje wszystkim organizacjom związkowym niezależnie od tego, czy mają one status organizacji reprezentatywnej, czy niereprezentatywnej. Również wniesienie zastrzeżenia przez inny związek zawodowy skutkuje koniecznością wystąpienia przez organizację związkową z wnioskiem do sądu o ustalenie liczby członków pod rygorem utraty uprawnień w razie zaniechania tego obowiązku.

Wprowadzone rozwiązanie w zakresie możliwości zweryfikowania danych o liczbie członków podanych przez związek zawodowy należy oceniać bardzo pozytywnie. Procedura ta pozwala rozwiać często pojawiające się wątpliwości co do tego, czy związek 
zawodowy przekazuje prawdziwe informacje. Ma ona znaczenie zarówno dla pracodawcy, który uzyskuje informacje, czy organizacja związkowa faktycznie liczy minimalną liczbę członków, od której uzależniona jest możliwość korzystania z uprawnień związkowych, jak i dla innych związków, dla których rzeczywista liczba członków konkurencyjnej organizacji związkowej będzie ważna w kontekście ustalenia, która z nich ma przymiot reprezentatywnej. Można mieć jedynie wątpliwości, czy wprowadzony przez ustawodawcę sześćdziesięciodniowy termin na dokonanie przez sąd weryfikacji podanych przez związek zawodowy danych będzie, wobec znacznego obciążenia sądów, dochowywany.

\section{Zakaz dyskryminacji ze względu na przynależność związkową}

Nowym przepisem obowiązującym od 1 stycznia 2019 r. jest przepis wprowadzający zakaz dyskryminacji ze względu na przynależność związkową. Również przed wejściem w życie nowelizacji ustawy o związkach zawodowych nie dopuszczano różnicowania pracowników ze względu na ich przynależność związkową (Szewczyk 2013, s. 24). Wprowadzony jednak do ustawy o związkach zawodowych art. 3 w nowym brzmieniu precyzuje zakres ochrony, określa podmioty, które są chronione przed nierównym traktowaniem, a także konsekwencje złamania zakazu nierównego traktowania przez pracodawcę.

Art. 3 u.z.z. zakazuje różnicowania sytuacji osób świadczących pracę ze względu na przynależność do związku zawodowego. Członek związku zawodowego nie powinien być traktowany gorzej niż osoby nienależące do związku. Jednak nie tylko przynależność do związku zawodowego nie może być kryterium różnicującym osoby zatrudnione. Nie jest dozwolone również traktowanie kogoś gorzej z powodu tego, że do związku zawodowego nie należy (np. przez odmowę określonych świadczeń, które pracodawca postanowił wypłacać tylko członkom związku zawodowego). Wreszcie za kryterium niedozwolonego różnicowania zostało również uznane wykonywanie funkcji związkowej (np. nie można traktować pracownika odmiennie ze względu na pełnienie przez niego określonej funkcji w zarządzie związku zawodowego).

Ze względu na powyższe czynniki pracodawca nie powinien różnicować pracujących we wszystkich obszarach związanych z zatrudnieniem. Ustawodawca $\mathrm{w}$ art. 3 u.z.z. wskazał najistotniejsze z niedozwolonych działań, a mianowicie takie, którego skutkiem jest w szczególności:

1) odmowa nawiązania lub rozwiązanie stosunku prawnego,

2) niekorzystne ukształtowanie wynagrodzenia za pracę zarobkową lub innych warunków zatrudnienia albo pominięcie przy awansowaniu lub przyznawaniu innych świadczeń związanych z pracą zarobkową,

3) pominięcie przy typowaniu do udziału w szkoleniach podnoszących kwalifikacje zawodowe (Czarnecki i in. 2019, s. 40-43).

Powyższe oznacza, że pracodawca nie może odmówić przedłużenia umowy z tego powodu, że dana osoba jest działaczem związkowym. Podobnie prowadzenie działalności związkowej nie może skutkować pominięciem przy przyznawaniu nagrody. 
Nowe przepisy zakazują nierównego traktowania ze względu na przynależność do związku zawodowego zarówno pracowników, jak i osób, które świadczącą pracę za wynagrodzeniem na innej podstawie niż stosunek pracy, jeżeli nie zatrudniają do tego rodzaju pracy innych osób. art. 3 u.z.z. ochronę rozciąga również na 1) emerytów i rencistów, 2) osoby bezrobotne, 3) wolontariuszy, stażystów i inne osoby, które świadczą pracę bez wynagrodzenia, 4) funkcjonariuszy Policji, Straży Granicznej, Służby Celno-Skarbowej i Służby Więziennej oraz strażaków Państwowej Straży Pożarnej, a także pracowników Najwyższej Izby Kontroli.

Oczywiście, powyższe nie oznacza, że konieczne jest identyczne traktowanie wyżej wymienionych osób (np. pracowników i usługobiorców), a jedynie że nie można odmiennie ukształtować praw i obowiązków tych osób wyłącznie ze względu na to, że jedna jest członkiem związku zawodowego, a druga nie.

W niektórych przypadkach pracodawca będzie jednak uprawniony odmiennie potraktować pracowników właśnie ze względu na przynależność związkową. Będzie tak, kiedy takie odmienne traktowanie jest uzasadnione obiektywnymi powodami. Dla przykładu można wskazać sytuację, gdy pracodawca odmówi zatrudnienia związkowca, a to $\mathrm{z}$ tego względu, że działalność ta jest często prowadzona $\mathrm{z}$ rażącym naruszeniem obowiązujących przepisów. Innym przykładem, kiedy odmienne traktowanie związkowców i niezwiązkowców jest dopuszczalne, może być zezwolenie na wcześniejsze zakończenie pracy wyłącznie członkom związku zawodowego w celu umożliwienia im udziału w wyborach władz tego związku.

W takim wypadku, w razie sporu, to na pracodawcy będzie spoczywał obowiązek wykazania, że obiektywne okoliczności rzeczywiście wystąpiły. Zatrudniony będzie musiał jedynie wykazać, że miało miejsce odmienne zachowanie pracodawcy wobec niego ze względu na przynależność (lub brak przynależności) do związku zawodowego.

Powołanie się na zakaz różnicowania ze względu na przynależność związkową przez zatrudnionego nie może być podstawą wyciągnięcia wobec tej osoby jakichkolwiek negatywnych konsekwencji. Przepisy ustawy o związkach zawodowych odsyłają tu do art. $18^{3 e}$ k.p. (Król 2004, s. 94 i n.; Sobczyk 2014, s. 61). Stanowi on, że skorzystanie przez pracownika z uprawnień przysługujących z tytułu naruszenia zasady równego traktowania w zatrudnieniu nie może być podstawą niekorzystnego traktowania pracownika, a także nie może powodować jakichkolwiek negatywnych konsekwencji wobec pracownika, a zwłaszcza stanowić uzasadnienia wypowiedzenia przez pracodawcę stosunku pracy lub jego rozwiązania bez wypowiedzenia.

Co więcej, negatywne konsekwencje nie powinny spotkać również osoby, która udzieliła w jakiejkolwiek formie wsparcia zatrudnionemu korzystającemu z uprawnień przysługujących z tytułu naruszenia zasady równego traktowania w zatrudnieniu ze względu na przynależność związkową.

Jeśli pracodawca, wbrew ustanowionemu zakazowi, nierówno potraktuje zatrudnionego, osoba taka może domagać się zapłaty odszkodowania. Minimalna kwota odszkodowania została ustanowiona na poziomie minimalnego wynagrodzenia za pracę. Ustawodawca nie wprowadził natomiast górnej granicy kwoty, jaka może być 
zasądzona. Przyjmuje się, że odszkodowanie to powinno być skuteczne, proporcjonalne i odstraszające przed ponownym dopuszczeniem się przez pracodawcę czynu nierównego traktowania.

Inną sankcją za naruszenie zasady równego traktowania jest nieważność postanowienia umów i innych aktów, na podstawie których inne niż pracownicy osoby świadczą pracę, naruszające zasadę równego traktowania w zatrudnieniu z powodu przynależności do związku zawodowego (jak też pozostawania poza nim albo wykonywania funkcji związkowej). Zamiast takich postanowień stosuje się odpowiednie przepisy prawa regulujące stosunek prawny łączący te osoby z pracodawcą, a w razie braku takich przepisów postanowienia te zastępuje się odpowiednimi postanowieniami niemającymi charakteru dyskryminacyjnego. Powyższe sprawy będą rozpatrywane przez sąd pracy.

Wprowadzone rozwiązania chronią związkowców przed nierównym traktowaniem. Zakres ochrony został ustanowiony bardzo szeroko i jest to konsekwencją nadania prawa do wstępowania do związku zawodowego dużo szerszej grupie osób. Wydaje się, że ustawodawca nie traktuje zakazu odmiennego traktowania ze względu na przynależność związkową jako kolejnej formy niedozwolonej dyskryminacji, ale jako typu nierównego traktowania. Z tego względu nie wszystkie przepisy Kodeksu pracy dotyczące dyskryminacji znajdą zastosowanie $\mathrm{w}$ razie nierównego traktowania zatrudnionego ze względu na jego działalność związkową.

\section{Prawo organizacji związkowej do informacji}

Prawo do domagania się informacji przez organizację związkową zostało uregulowane w art. 28 u.z.z. (Baran 2007, s. 249; Wujczyk 2007, s. 133-134; Piątkowski 2008, s. 259-262; Florek 2019, s. 2). Organizacja związkowa może domagać się - a pracodawca jest obowiązany udzielić - tych informacji, które są niezbędne do prowadzenia działalności związkowej. Ustawodawca wskazał przykładowo, jakie informacje mają taki charakter. Są to informacje dotyczące:

1) warunków pracy i zasad wynagradzania,

2) działalności i sytuacji ekonomicznej pracodawcy związanych z zatrudnieniem oraz przewidywanych w tym zakresie zmian,

3) stanu, struktury i przewidywanych zmian zatrudnienia oraz działań mających na celu utrzymanie poziomu zatrudnienia,

4) działań, które mogą powodować istotne zmiany w organizacji pracy lub podstawach zatrudnienia.

Wymienione w przepisie informacje, jakie pracodawca powinien przekazać organizacji związkowej na jej żądanie, rodzą liczne wątpliwości. Pojęcie warunków pracy należy rozumieć szeroko. W konsekwencji do warunków pracy należy zaliczyć również takie elementy jak środowisko pracy, organizacja pracy, warunki BHP i przeciwpożarowe, wyposażenie zakładu pracy, infrastruktura społeczna w zakładzie, dostępność do służby 
zdrowia gwarantowana przez pracodawcę, zapewnienie przez pracodawcę dojazdu do pracy, możliwość podnoszenia kwalifikacji i szkoleń, zagadnienia związane z czasem pracy, urlopami czy ochroną trwałości zatrudnienia.

Z kolei pojęcie zasad wynagrodzenia zostało wyjaśnione w wyroku Sądu Najwyższego z 16 lipca 1993 r. (I PZP 28/93, OSNC 1994, nr 1, poz. 2). Sąd Najwyższy wskazał, że przez pojęcie „informacji o zasadach wynagradzania” nie można rozumieć tylko informacji o przepisach regulujących kształtowanie wynagrodzeń, które przecież ze swej istoty są jawne i powszechnie dostępne. Informacja o zasadach wynagradzania obejmuje dane o konkretnie występujących w zakładzie pracy zjawiskach gospodarczych, o jego sytuacji finansowej, określonych funduszach, w tym zwłaszcza funduszu płac, czy nawet o wysokości wynagrodzeń określonej grupy zawodowej lub o kształtowaniu się wynagrodzeń na określonych rodzajach stanowisk. Związki zawodowe nie mają natomiast uprawnienia do żądania od pracodawcy udzielenia informacji o wysokości wynagrodzenia pracownika bez jego zgody.

Pod pojęciem działalności i sytuacji ekonomicznej pracodawcy należy rozumieć całokształt podejmowanych przez pracodawcę działań związanych zarówno z prowadzeniem przez niego zakładu pracy, w tym sytuację majątkową i finansową pracodawcy, jak też jego pozycją na rynku, na którym działa, wpływającą na sytuację pracowników. Pracodawca jest również zobowiązany do przekazania informacji o zmianach dotyczących swojej działalności i sytuacji ekonomicznej. Chodzi o takie zmiany, które potencjalnie mogą mieć wpływ na sytuację pracowników.

Przez stan zatrudnienia należy rozumieć liczbę osób zatrudnionych na podstawie zarówno umowy o pracę, jak i umów cywilnoprawnych. Ta ostatnia dana ma o tyle znaczenie, że pozwala związkom zawodowym zidentyfikować rzeczywiste potrzeby pracodawcy co do liczby zatrudnionych. Z kolei struktura zatrudnienia odnosi się zarówno do grup zawodowych zatrudnionych przez danego pracodawcę, podziału pracowników na poszczególne stopnie zaszeregowania, jak też rodzaju umów o pracę, na podstawie których zatrudnieni są pracownicy. W grę mogą wchodzić również dane o strukturze zatrudnienia ze względu na kryterium płci, wieku, wykształcenia lub innych istotnych czynników. Pracodawca może być zobowiązany do przekazania informacji o terytorialnej strukturze zatrudnienia, jeśli ma to znaczenie dla sytuacji pracowników.

Przewidywane zmiany zatrudnienia odnoszą się zarówno do planowanego istotnego zwiększenia liczby zatrudnionych, jak i do działań skutkujących zmniejszeniem poziomu zatrudnienia. W niektórych przypadkach konieczne będzie poinformowanie o zwolnieniach niemających przymiotu zwolnień grupowych. Może tak być w przypadku mniejszych pracodawców, w sytuacji rozłożenia procesu zwolnień na okres dłuższy niż 30 dni lub zwolnień, które prowadzą do istotnych zmian w funkcjonowaniu pracodawcy (np. zwolnienia wszystkich pracowników danego szczebla). W mojej ocenie pracodawca nie powinien ograniczać się jedynie do przedstawienia tego, iż zmieni się liczba pracowników, ale również powinien określić choćby przybliżoną liczbę zwalnianych lub zatrudnianych osób, a także działy lub jednostki wchodzące 
w struktury pracodawcy, w których te zdarzenia będą miały miejsce. Jeśli istotny wpływ na poziom zatrudnienia będzie miała decyzja pracodawcy o nieprzedłużaniu umów zawartych na czas określony, również ta informacja powinna zostać przekazana związkom zawodowym.

Informacje, jakie zobowiązany jest przekazać pracodawca, powinny obejmować fluktuacje zatrudnienia w odniesieniu do zarówno całości załogi, jak i poszczególnych grup zawodowych.

Na pracodawcy ciąży również obowiązek informowania o działaniach zmierzających do utrzymania poziomu zatrudnienia. W grę mogą tu wchodzić dążenia do zmniejszania planowanych zwolnień czy przekwalifikowania pracowników. Obowiązkiem informacyjnym mogą być objęte również działania mające na celu jedynie zmniejszenie ryzyka spadku poziomu zatrudnienia. Takimi mogą być organizacja kursów i szkoleń mających podnieść kwalifikacje pracowników.

Wreszcie - pracodawca powinien przekazać na wniosek związku zawodowego informacje dotyczące działań, które mogą powodować istotne zmiany w organizacji pracy lub podstawach zatrudnienia. Zmiany organizacji pracy dotyczą zmian o charakterze zarówno strukturalnym, jak i technicznym (np. wprowadzenia nowych urządzeń, technologii czy metod pracy). Są to też przeobrażania w sposobie wykonywania pracy, na przykład w zakresie stosowanego systemu pracy, zasad podległości służbowej, wprowadzenie innych niż dotychczasowe godzin rozpoczynania pracy. Podstawy zatrudnienia odnoszą się nie tylko do rodzaju umów o pracę, jakie są zawierane w zakładzie pracy, i podstaw zatrudnienia w ramach stosunku pracy, lecz także do decyzji dotyczących wyboru stosunku pracy lub stosunku cywilnoprawnych jako podstawy zatrudnienia w zakładzie pracy. W mojej ocenie pracodawca powinien poinformować również o decyzji o korzystaniu z pracowników firm zewnętrznych (tzw. outsourcing).

Pamiętać należy, że ustawodawca nie sformułował zamkniętego katalogu informacji, które pracodawca ma obowiązek przekazać związkowi zawodowemu. Związek może domagać się również innych informacji, o ile są mu niezbędne do prowadzenia działalności związkowej. Można tu wskazać na przykład na informacje dotyczące mechanizmów funkcjonowania funduszy zakładowych, mechanizmów regulacji statusu socjalnobytowego pracowników i emerytów czy informacje o pobieraniu przez pracodawcę składki związkowej.

Rodzi się pytanie: co z informacjami, które są objęte tajemnicą przedsiębiorstwa (Zwolińska 2012, s. 300-304)? W przypadku gdy informacje te są udzielane w ramach rokowań nad treścią układu zbiorowego pracy, sprawa wydaje się jasna. Zgodnie $\mathrm{z}$ art. $241^{4}$ $\$ 2$ k.p. przedstawiciele związków zawodowych są obowiązani do nieujawniania uzyskanych od pracodawcy informacji stanowiących tajemnicę przedsiębiorstwa w rozumieniu przepisów ustawy z dn. 16 kwietnia 1993 r. o zwalczaniu nieuczciwej konkurencji (Dz.U. 2019, poz. 1010 tekst jedn.). Natomiast brak jest wyraźnej regulacji, która uprawniałaby pracodawcę do odmowy przekazania czy choćby zakazania ujawniania przez związkowców uzyskanych informacji załodze. Rozwiązaniem może być tu zastosowanie w drodze analogii rozwiązania przewidzianego w ustawie z dn. kwietnia 2006 r. o informowaniu 
pracowników i przeprowadzaniu z nimi konsultacji (Dz.U. 2006, nr 79, poz. 550 ze zm.), która reguluje zasady przekazywania danych będących tajemnicą przedsiębiorstwa radzie pracowników. Oznaczałoby to, że członkowie związku zawodowego byliby zobowiązani do nieujawnienia uzyskanych w związku z pełnioną funkcją, na podstawie art. 28 u.z.z., informacji stanowiących tajemnicę przedsiębiorstwa, co do których pracodawca zastrzegł obowiązek zachowania ich poufności. Obowiązek nieujawniania uzyskanych informacji istniałby również po zaprzestaniu pełnienia funkcji, lecz nie dłużej niż przez okres 3 lat. Dodatkowo, analogiczne stosowanie przepisów regulujących udzielanie informacji radzie pracowników pozwoliłoby pracodawcy, w szczególnie uzasadnionych przypadkach, nie udostępniać związkowi zawodowemu informacji, których ujawnienie mogłoby, według obiektywnych kryteriów, poważnie zakłócić działalność przedsiębiorstwa lub zakładu, których dotyczą, albo narazić je na znaczną szkodę.

Ustawa o związkach zawodowych nie wskazuje, w jakiej formie organizacja związkowa powinna wystąpić z wnioskiem o udzielnie informacji, należy więc dopuścić formę zarówno pisemną, jak i ustną. W tej samej formie może być udzielona odpowiedź, pierwszeństwo należy dać jednak tej, która została wskazana przez wnioskującego. Moim zdaniem, mimo że zazwyczaj rzeczywiście forma pisemna będzie najwłaściwsza, nie można jednak wykluczyć sytuacji, gdy lepszym rozwiązaniem będzie wykorzystanie innego trybu przekazywania informacji, na przykład wówczas gdy konieczne będzie ich szybkie udzielenie, praktyczniejsze może być ustne przekazanie potrzebnych informacji.

Znowelizowane przepisy wskazują natomiast termin, w jakim pracodawca powinien przekazać informacje - jest do tego zobowiązany w terminie 30 dni od dnia otrzymania wniosku. Przekroczenie tego terminu przez pracodawcę może być uznane za utrudnianie wykonywania działalności związkowej, co jest sankcjonowane karą grzywny lub karą ograniczenia wolności.

\section{Zwolnienie pracownika od pracy zawodowej do czynności doraźnych}

Wraz z nowelizacją przepisów o związkach zawodowych prawo do skorzystania ze zwolnienia na dokonanie czynności doraźnej zyskali działacze związkowi zatrudnieni na podstawie umów cywilnoprawnych. Liczne wątpliwości budzi jednak to, kiedy pracodawca jest obowiązany udzielić takiego zwolnienia. Przepisy ustawy o związkach zawodowych przewidują zwolnienie od pracy na czas niezbędny do dokonania czynności doraźnej w dwóch przypadkach: gdy wynika to z pełnionej przez daną osobę funkcji związkowej w zakładzie pracy (art. 31 ust. 3 u.z.z.) oraz gdy jest to konieczne ze względu na pełnioną przez nią funkcję związkową poza zakładem pracy (art. 25 ust. 5 u.z.z.).

Prawo do zwolnienia przysługuje, jeżeli dotyczy to czynności, która:

1) jest doraźna,

2) wynika z funkcji związkowej,

3) nie może być wykonywana w czasie wolnym od pracy. 
Znowelizowane przepisy nie doprecyzowały, co należy rozumieć przez pojęcie doraźności. Można tu wyróżnić trzy grupy poglądów.

Według poglądów z pierwszej grupy czynność doraźna to taka, która nie mogła zostać wcześniej zaplanowana, a więc ma charakter niecierpiący zwłoki, natychmiastowy, jest dorywcza. Według drugie poglądu doraźność należy rozumieć jako działanie jednorazowe lub incydentalne, „od przypadku do przypadku”. Wreszcie można spotkać się ze stanowiskiem wskazującym, że pojęcie doraźności należy wykładać szeroko, przyjmując, że charakter doraźny ma każdy racjonalny przypadek, który w znaczeniu potocznym może być uznany za doraźny (a więc można żądać zwolnienia zarówno gdy dana czynność była niezaplanowana jak i w sytuacji gdy była planowana, ale ma charakter jednostkowy; Piątkowski 2012, s. 474 i n., wraz z przyw. literaturą).

W mojej ocenie doraźność powinna być rozumiana jako czynność, która wystąpiła nagle, nie była wcześniej zaplanowana, ma więc charakter działania ad hoc. Wydaje się, że w tym kierunku zmierza również orzecznictwo. W wyroku z 14 grudnia $2017 \mathrm{r}$. (II PK 322/16, OSNP 2018, nr 11, poz. 146) Sąd Najwyższy zasygnalizował, że doraźność zawiera w sobie element nagłości i krótkotrwałości. Chodzi o to, aby działacz związkowy miał sposobność wykonania czynności, której nie dało się przewidzieć, a jest ona istotna z uwagi na pełnienie funkcji związkowej. Powyższe doprowadziło Sąd Najwyższy do konkluzji, że kilkudniowe szkolenie organizowane przez związek zawodowy w godzinach przeznaczonych na pracę nie stanowi czynności, o której mowa w art. 31 ust. 3 u.z.z. Tym samym przymiotu czynności doraźnej nie będzie miało również wcześniej zaplanowane posiedzenie zarządu organizacji związkowej - jest to bowiem normalny element działalności związkowej, który - co do zasady - jest i powinien być wcześniej zaplanowany.

Pojęcie pełnienia funkcji związkowej jest rozumiane szeroko. W grę wchodzą tu zarówno funkcje stałe (np. członkostwo w zarząadzie związku), jak i doraźne (np. udział w walnym zgromadzeniu jako delegat, występowanie w sądzie jako pełnomocnik procesowy czy reprezentowanie organizacji związkowej w trakcie rokowań lub mediacji). W tym miejscu warto wskazać, że udzielania zwolnień na dokonanie czynności doraźnej nie mogą się domagać członkowie zarządu związku, którzy zostali całkowicie zwolnieni z obowiązku świadczenia pracy w trybie art. 31 ust. 1 u.z.z. - takie zwolnienia są wykluczone przez prawo do zwolnienia na dokonanie czynności doraźnej.

Wreszcie o czynności doraźnej można mówić, gdy jej wykonanie nie jest możliwe w czasie wolnym od pracy; w grę będą tu wchodzić sytuacje, gdy sam pracownik nie ma możliwości jej dokonania w czasie wolnym od pracy, a także gdy organizacja zakładowa, a nawet organizacja ponadzakładowa nie ma możliwości zaplanowania działań, w których ma uczestniczyć związkowiec, poza jego czasem pracy.

Prawo do zwolnienia od pracy zawodowej z zachowaniem prawa do wynagrodzenia na czas niezbędny do wykonania doraźnej czynności przysługuje pracownikowi, jeśli potrzeba dokonania takiej czynności wynika z jego funkcji związkowej pełnionej zarówno w ramach zakładu pracy, jak i poza nim.

Po nowelizacji prawo do korzystania ze zwolnienia na dokonanie czynności doraźnej uzyskały również inne niż pracownik osoby wykonujące pracę zarobkową. Prawo to 
będzie więc przysługiwało osobom wykonującym pracę na podstawie zarówno umowy o świadczenie usług, umowy zlecenia, jak i umowy o współpracę - ta ostatnia najczęściej jest podstawą współdziałania $\mathrm{z}$ osobami prowadzącymi jednoosobową działalność gospodarczą. Z prawa do zwolnienia na dokonanie czynności doraźnej będą mogli również skorzystać praktykanci, o ile za wykonywanie praktyki otrzymują wynagrodzenie.

Przepisy wyraźnie jednak zastrzegają, że w przypadku osoby innej niż pracownik korzystanie ze zwolnienia na dokonanie czynności doraźnej nie skutkuje przedłużeniem umowy, jeśli w umowie tej określono termin wykonania pracy. Tym samym usługobiorca, który zdecyduje się na skorzystanie ze zwolnienia na dokonanie czynności doraźnej, musi się liczyć z tym, że będzie miał mniej czasu na realizację usługi, jaką zobowiązał się wykonać.

Należy wskazać, że przepisy nie ograniczają liczby osób, które mogą korzystać ze zwolnienia, natomiast możliwe jest określenie w układzie zbiorowym pracy limitu czasu zwolnień od pracy zawodowej na czas niezbędny do wykonania doraźnej czynności wynikającej z funkcji związkowej osób wykonujących pracę zarobkową. W mojej ocenie to ograniczenie może dotyczyć zwolnienia na dokonanie czynności wynikającej z pełnionej funkcji zarówno w zakładzie pracy, jak i poza nim.

Za czas zwolnienia na dokonanie czynności doraźnej pracownik lub osoba wykonująca pracę zarobkową na innej podstawie niż stosunek pracy zachowują wynagrodzenie.

W przypadku pracowników należy przyjąć, że wynagrodzenie za okres nieobecności będzie obliczane na podstawie przepisów rozporządzenia z dn. 29 maja 1996 r. Ministra Pracy i Polityki Socjalnej w sprawie sposobu ustalania wynagrodzenia w okresie niewykonywania pracy oraz wynagrodzenia stanowiącego podstawę obliczania odszkodowań, odpraw, dodatków wyrównawczych do wynagrodzenia oraz innych należności przewidzianych w Kodeksie pracy (Dz.U. 2017, poz. 927 tekst jedn.). Tym samym należy stosować zasady obowiązujące przy ustalaniu wynagrodzenia za urlop, z tym że składniki wynagrodzenia ustalane w wysokości przeciętnej oblicza się z miesiąca, w którym przypadło zwolnienie od pracy lub okres niewykonywania pracy.

Większe trudności rodzi ustalenie, jakie wynagrodzenie powinny otrzymać osoby wykonujące pracę na innej podstawie niż stosunek pracy (np. usługobiorcy). W mojej ocenie do czasu wydania przez ustawodawcę szczególnych regulacji należy stosować odpowiednio przepisy regulujące ustalenie wynagrodzenia osób zatrudnionych na innej podstawie niż stosunek pracy w okresie ich zwolnienia od pracy w związku $\mathrm{z}$ pełnieniem funkcji $\mathrm{w}$ ramach zarządu organizacji związkowej, tj. rozporządzenia Rady Ministrów z dn. 27 listopada 2018 r. w sprawie trybu udzielenia i korzystania ze zwolnienia z obowiązku świadczenia pracy na okres kadencji w zarządzie zakładowej organizacji związkowej przysługującego osobie wykonującej pracę zarobkową, sposobu ustalenia wysokości wynagrodzenia albo świadczenia pieniężnego przysługującego osobie w okresie zwolnienia od pracy oraz wynikających z tego tytułu uprawnień i świadczeń (Dz.U. 2018, poz. 2323). Przewidują one, że innej niż pracownik osobie wykonującej pracę zarobkową $\mathrm{w}$ okresie zwolnienia od pracy ustala się miesięczne świadczenie pieniężne w wysokości przeciętnego wynagrodzenia przysługującego tej osobie z okresu 
6 miesięcy poprzedzających okres zwolnienia od pracy, a jeżeli osoba ta świadczy pracę przez okres krótszy niż 6 miesięcy - w wysokości przeciętnego wynagrodzenia przysługującego tej osobie $\mathrm{z}$ całego tego okresu. Jeżeli osoba ta korzysta ze zwolnienia w niepełnym wymiarze godzin, wysokość świadczenia pieniężnego za czas zwolnienia od pracy ustala się proporcjonalnie do tego wymiaru czasu pracy, przy czym wynagrodzenie jest wypłacane na zasadach wynikających z umowy zawartej z tą osobą. Odpowiednie stosowanie tych przepisów pozwoli określić wysokość należnego wynagrodzenia za czas zezwolenia na dokonanie czynności doraźnej osobom zatrudnionym na innej podstawie niż umowa o pracę.

Należy podkreślić, że przepisy wprowadzają szczególne zastrzeżenie co do wynagrodzenia należnego osobie zatrudnionej na innej podstawie niż stosunek pracy. Osoba ta zachowuje prawo do wynagrodzenia za czas zwolnienia na dokonanie czynności doraźnej, chyba że przepisy szczególne stanowią inaczej. Sformułowanie to nie jest do końca jasne. W uzasadnieniu do nowelizacji ustawy o związkach zawodowych wskazano, że:

W przypadku gdy wynagrodzenie danej osoby będzie miało charakter wynagrodzenia ryczałtowego i jego wysokość nie będzie zależała od liczby przepracowanych godzin pracy albo gdy wypłata wynagrodzenia będzie uzależniona od wyników pracy (np. wykonania dzieła), odrębne wynagrodzenie na czas niezbędny do wykonania doraźnej czynności nie będzie przysługiwało.

Takim przypadkiem może być praca na podstawie umowy o dzieło. Wykonawcy dzieła będzie przysługiwało wynagrodzenie dopiero po wykonaniu dzieła zgodnie z umową nie będzie mógł się więc domagać wynagrodzenia za okres zwolnienia na dokonanie czynności doraźnej.

Pracownik nie może samodzielnie zaprzestać pracy. W celu dokonania czynności doraźnej musi uzyskać zgodę pracodawcy. Nie uważam za słuszne stanowisk, które wskazują, że uprawnienie do doraźnego zwolnienia nie podlega kontroli pracodawcy w zakresie merytorycznym. Jeśli pracodawca stwierdzi, że nie zostały spełnione warunki wymagane dla dokonania czynności doraźnej, to może odmówić zwolnienia pracownika z pracy. Co więcej, w szczególnie uzasadnionych przypadkach, gdy nieobecność pracownika zagraża istotnie interesom pracodawcy, może on odmówić zwolnienia pracownika od pracy. Nieobecność pracownika, który nie stawia się do pracy i samodzielnie „udziela” sobie zwolnienia od pracy, na które pracodawca nie wyraził zgody, jest nieobecnością nieusprawiedliwioną, która może uzasadniać rozwiązanie stosunku pracy w trybie art. 52 k.p. (por. wyrok SN z 18 lutego 2012 r., II PK 196/2010, LexPolonica nr 3026594).

Zwolnienie pracownika od pracy zawodowej do czynności doraźnych następuje według zasad przewidzianych w rozporządzeniu Ministra Pracy i Polityki Socjalnej z dnia 15 maja 1996 r. w sprawie sposobu usprawiedliwiania nieobecności w pracy oraz udzielania pracownikom zwolnień od pracy (Dz.U. 2014, poz. 1632 tekst jedn. ze zm.). Takie stanowisko zajął SN w wyrokach z 13 stycznia 2005 r. (II PK 117/04, OSNP 2005, nr 16, poz. 246) i 2 czerwca 2010 r. (II PK 367/09, OSNP 2011, nr 21-22, poz. 274). 
W mojej ocenie z wnioskiem o zwolnienie powinien wystąpić sam pracownik lub też organizacja związkowa, w ramach której pełni funkcję - przy czym w tym ostatnim przypadku pracownik powinien potwierdzić, że ze zwolnienia od pracy chce skorzystać. Wniosek może mieć dowolną formę: pisemną, elektroniczną, ale też ustną. Pracodawca jest uprawniony do żądania od wnioskodawcy uprawdopodobnienia, że konkretna czynność ma charakter doraźny.

\section{Zasady wszczynania sporu zbiorowego}

Grupa osób świadczących pracę na innej podstawie niż stosunek pracy nie tylko uzyskała prawo zakładania związków zawodowych i prowadzenia działalności związkowej, ale została objęta również przepisami ustawy z dn. 23 maja 1991 r. o rozwiązywaniu sporów zbiorowych (Dz.U. 2019, poz. 174 tekst jedn. ze zm.). Zgodnie z art. 6 tej ustawy jej przepisy odnoszące się do pracowników mają odpowiednie zastosowanie do innych niż pracownicy osób wykonujących pracę zarobkową. Na gruncie nowych regulacji przedmiotem sporu zbiorowego mogą być żądania dotyczące warunków pracy, płac lub świadczeń socjalnych oraz praw i wolności związkowych również innych niż pracownicy osób świadczących pracę, na przykład zleceniobiorców czy osób prowadzących jednoosobową działalność gospodarczą. Oznacza to, że w ramach sporu zbiorowego można na przykład domagać się wyższej stawki wynagrodzenia dla osób zatrudnionych na podstawie umów cywilnoprawnych czy wprowadzenia dla tej grupy świadczeń o charakterze socjalnym (np. paczki bożonarodzeniowej lub finansowania kart wstępu na basen).

Nie uległa zmianie ogólna zasada, że spór zbiorowy może wszcząć jedynie związek zawodowy. Po wprowadzonych zmianach może to być jednak nie tylko organizacja zrzeszająca samych pracowników, ale również taka, której większość członków, a nawet wszyscy, to osoby zatrudnione na podstawie umów cywilnoprawnych.

Pewne wątpliwości może budzić pytanie, czy związek zawodowy, który nie zrzesza osób zatrudnionych na podstawie umów cywilnoprawnych, może wszcząć spór zbiorowy, domagając się poprawy warunków, w jakich ta grupa zatrudnionych świadczy pracę. W mojej ocenie jest to dopuszczalne. Osoby zatrudnione na innej podstawie niż stosunek pracy są uprawnione do brania udziału we wszystkich etapach sporu zbiorowego. Mogą więc prowadzić z podmiotem, z którym mają zawarte umowy, rokowania, mediację i arbitraż. Mogą również podjąć strajk.

Ustawodawca nie uregulował zasad, na jakich strajk mogą prowadzić osoby niebędące pracownikami. Należy przyjąć, że będą to te sama zasady, które obowiązują pracowników (Światkowski 1994, s. 321; Baran 1998, s. 158; Cudowski 2005, s. 96; Świątkowski, Wujczyk 2010, s. 284; Żołyński 2011, s. 397-402; 2013, s. 305 i 308). Jeśli strajk jest legalny, udziału w nim nie można traktować jako naruszenia postanowień zawartej umowy.

Za czas strajku osoby prowadzące działalność zarobkową na innej podstawie niż stosunek pracy nie otrzymają wynagrodzenia. Okres strajku nie skutkuje natomiast 
utratą innych uprawnień, na przykład prawa do korzystania z samochodu podmiotu zatrudniającego do celów prywatnych, jeśli taka możliwość istnieje na mocy umowy.

Okres strajku nie jest też traktowany jako przerwa w zatrudnieniu w zakresie ustalania uprawnień uzależnionych od długości trwania umowy (np. w zakresie ustalenia długości wypowiedzenia - jeśli jest ono zależne od czasu pracy na rzecz danego podmiotu). Przerwa w wykonywaniu usługi ze względu na strajk nie oznacza natomiast, że usługodawca będzie zwolniony z wykonania całości usługi albo uzyska więcej czasu na jej wykonanie. Brak jest póki co przepisu, który wprowadzałby taki mechanizm. Osoby zatrudnione na podstawie umów cywilnoprawnych muszą się więc liczyć z tym, że jeśli z powodu strajku nie wykonają w terminie zamówionej usługi, mogą nie uzyskać umówionego wynagrodzenia. W szczególności będzie tak, jeśli z treści umowy wyraźnie wynika, że wynagrodzenie przysługuje wyłącznie za usługę wykonaną w całości w terminie.

Istotną konsekwencją nowych regulacji zarówno dla osób wykonujących pracę na innej podstawie niż stosunek pracy, jak i dla pracowników są zmiany w zakresie podejmowania decyzji o rozpoczęciu strajku. Musi go poprzedzać referendum strajkowe. Przed nowelizacją dla rozpoczęcia strajku wystarczająca była zgoda większości głosujących, jeśli w głosowaniu wzięło udział 50\% wszystkich pracowników. Po zmianie przepisów ważność referendum wymaga udziału 50\% wszystkich osób zatrudnionych w danym przedsiębiorstwie - a więc zarówno pracowników, jak i osób wykonujących pracę zarobkową na innej podstawie niż stosunek pracy. W wielu przypadkach może to znacznie utrudnić uzyskanie zgody załogi na podjęcie decyzji o strajku.

\section{Podsumowanie}

Pozytywnie należy ocenić przyznanie możliwości zrzeszania się w związkach zawodowych również osobom zatrudnionym na innej podstawie niż stosunek pracy. Wobec częstej formy wykonywania pracy na podstawie umów cywilnoprawnych jest to rozwiązanie sprzyjające realizacji zasady wolności zrzeszania się osób wykonujących pracę. W wielu przypadkach jednak nowe regulacje rodzą wątpliwości, a dotychczas obowiązujące przepisy nie zostały dostosowane do cywilnoprawnego charakteru umowy między podmiotem zatrudniającym a osobami niebędącymi pracownikami. Pierwszy okres obowiązywania nowych przepisów powinien być wykorzystany, aby sprawdzić, czy odpowiadają one potrzebom zbiorowych stosunków zatrudnienia obejmujących wszystkie osoby wykonujące pracę zarobkową. Już teraz można wskazać regulacje, które powinny być zmienione. Dotyczy to w szczególności, jak się wydaje, zasad prowadzenia sporów zbiorowych w imieniu osób zatrudnionych na umowach cywilnoprawnych, a także uprawnień takich osób wynikających z pełnienia przez nie funkcji związkowych. 


\section{Bibliografia}

Baran K.W. (1998) Zbiorowe prawo pracy: zarys wykładu z kazusami, Gdańsk-Kraków.

Baran K.W. (2007) [w:] K.W. Baran (red.), Zbiorowe prawo pracy: komentarz, Warszawa.

Baran K.W. (2018) O zakresie prawa koalicji w zwiazkach zawodowych po nowelizacji prawa związkowego z 5 lipca 2018 r., „Praca i Zabezpieczenie Społeczne”, nr 9.

Cudowski B. (2005) Podstawowe problemy zbiorowych stosunków pracy z udziałem pracowników tymczasowych, „Monitor Prawa Pracy”, nr 4.

Czarnecki P., Grzebyk P., Reda-Ciszewska A., Surdykowska B. (2019) Ustawa o związkach zawodowych: komentarz praktyczny z orzecznictwem, Warszawa.

Czubak M. (2003) Nowelizacja przepisów ustawy o związkach zawodowych, „Praca i Zabezpieczenie Społeczne", nr 8.

Dubowik A. (2003) Zakładowa organizacja związkowa po nowelizacji ustawy o związkach zawodowych, „Praca i Zabezpieczenie Społeczne”, nr 9.

Dubowik A. (2006) Liczba członków zakładowej organizacji związkowej jako czynnik determinujący jej status, „Praca i Zabezpieczenie Społeczne”, nr 9.

Florek L. (2018) Zakres podmiotowy wolności związkowej [w:] J. Stelina, J. Szmit (red.), Zbiorowe prawo zatrudnienia, Warszawa.

Florek L. (2019) Prawo związku zawodowego do informacji, „Praca i Zabezpieczenie Społeczne”, nr 5 .

Król J. (2004) Nowelizacja Kodeksu pracy dotycząca równego traktowania w zatrudnieniu na tle regulacji wspólnotowych, „Radca Prawny”, nr 4.

Piątkowski J. (2008) Uprawnienia zakładowej organizacji związkowej, Toruń.

Piątkowski J. (2012) Doraźne zwolnienie od pracy w ustawie o związkach zawodowych [w:] Z. Hajn (red.), Związkowe przedstawicielstwo pracowników zakładu pracy, Warszawa.

Płażek S., Sobczyk A. (2003) Wątpliwości wokół interpretacji nowych przepisów ustawyo związkach zawodowych, „Praca i Zabezpieczenie Społeczne”, nr 8.

Sobczyk A. (red.) (2014) Kodeks pracy: komentarz, Warszawa.

Szewczyk H. (2013) Dyskryminacja w zatrudnieniu ze względu na przynależność związkowa, „Praca i Zabezpieczenie Społeczne”, nr 4.

Szmit J. (2012) Weryfikacja przez pracodawcę oświadczeń składanych przez zakładową organizacje związkowa [w:] Z. Hajn (red.), Związkowe przedstawicielstwo pracowników zakładu pracy, Warszawa.

Światkowski A.M. (1994) Rozwiązywanie sporów zbiorowych pracy, „Studia z Zakresu Prawa Pracy i Polityki Społecznej", z. 1.

Świątkowski A.M., Wujczyk M. (2010) Polskie regulacje z zakresu rozwiązywania sporów zbiorowych w świetle standardów europejskich na przykładzie prawa do strajku [w:] A. Wypych-Żywicka, M. Tomaszewska, J. Stelina (red.), Zbiorowe prawo pracy w XXI wieku: międzynarodowa konferencja naukowa z okazji trzydziestej rocznicy powstania NSZZ „Solidarność”, Gdańsk.

Tomaszewska M. (2014) [w:] Baran K.W. (red.), System prawa pracy, t. 5: Zbiorowe prawo pracy, Warszawa. 
Wujczyk M. (2007) Prawo związków zawodowych do informacji o sytuacji zakładu pracy i możliwość jego dochodzenia na drodze sądowej, „Studia z Zakresu Prawa Pracy i Polityki Społecznej", z. 1.

Zwolińska A. (2012) Prawo zakładowej organizacji związkowej do informacji [w:] Z. Hajn (red.), Związkowe przedstawicielstwo pracowników zakładu pracy, Warszawa.

Żołyński J. (2011) Obowiązki uczestników i organizatorów strajku, „Monitor Prawa Pracy”, nr 8. Żołyński J. (2013) Strajk i inne rodzaje akcji protestacyjnych jako metoda rozwiązywania sporów zbiorowych, Warszawa.

\section{Orzecznictwo}

Wyrok SN z 16 lipca 1993 r., I PZP 28/93, OSNC 1994, nr 1, poz. 2.

Wyrok SN z 13 stycznia 2005 r., II PK 117/04, OSNP 2005, nr 16, poz. 246.

Wyrok SN z 2 czerwca 2010 r., II PK 367/09, OSNP 2011, nr 21-22, poz. 274.

Wyrok SN z 18 lutego 2012 r., II PK 196/2010, LexPolonica nr 3026594.

Wyrok SN z 14 grudnia 2017 r., II PK 322/16, OSNP 2018, nr 11, poz. 146.

Wyrok TK z 2 czerwca 2015 r., K 1/13, Dz.U. 2005, poz. 791. 